\title{
Terminological Aspects of a cognitive Structure REFUGEE / БIЖЕНЕЦЬ in modern legal Discourse
}

Terminologiczne aspekty struktury poznawczej REFUGEE / БІЖЕНЕЦЬ we współczesnym dyskursie prawniczym

Svitlana MATVIEIEVA/СВITЛАНА MATВЄЄBA ${ }^{1}$

National Pedagogical Dragomanov University (Ukraine)

Nataliya LEMISH/HATAЛІЯ ЛЕМIШ ${ }^{2}$

National Pedagogical Dragomanov University (Ukraine)

\begin{abstract}
Summary
The article deals with the cognition-defined approaches to understanding terms as complex structures enabling the conceptualization and verbalization of fragments of the worldview of professional social groups. The authors discuss aspects of the terminological meaning of the cognitive structure of REFUGEE / БІЖЕНЕЦЬ in the English and Ukrainian languages, the transformation of the meaning of modern legal terms and the evolution of their legal interpretation, as well as analyse historical and social grounds for such changes. Special attention
\end{abstract}

\footnotetext{
1 https://orcid.org/0000-0002-8357-9366

National Pedagogical Dragomanov University

Department of Applied Language Studies, Comparative Linguistics and Translation sam141175@gmail.com

2 https://orcid.org/0000-0001-5321-4705

National Pedagogical Dragomanov University

Department of Applied Language Studies, Comparative Linguistics and Translation

lemish1972@gmail.com
} 
is paid to the lexical item's thesaurus links in the legal professional discourse which provide for the verbalization of the term in specific communicative situations.

Keywords: cognitive terminological structure, a term, legal discourse, thesaurus, definition

\section{Streszczenie}

Niniejszy artykuł dotyczy poznawczo zdefiniowanych podejść do rozumienia terminów jako złożonych struktur, umożliwiających konceptualizację i werbalizację fragmentów światopoglądu zawodowego. Autorzy badają aspekty znaczenia terminologicznego struktury poznawczej REFUGEE / БІЖЕНЕЦЬ w języku angielskim i ukraińskim, transformację znaczenia współczesnych terminów prawniczych i ewolucję ich interpretacji prawnej, a także analizują historyczne i społeczne podstawy tych zmian. Szczególną uwagę zwraca się na powiązania $\mathrm{w}$ tezaurusie dla danej jednostki w ramach prawniczego dyskursu zawodowego, zapewniające werbalizację terminu w określonej sytuacji komunikacyjnej.

Słowa kluczowe: poznawcza/kognitywna struktura terminologiczna, termin, dyskurs prawniczy, tezaurus, definicja

\section{Introduction}

Modern terminology science is characterized by cognitive direction of the terms study considering the mental processes of their nomination, the role of terms in the processes of scientific thinking and cognition, resulting in the formation of the cognitive-defined approaches to understanding terms as complex structures enabling conceptualization and verbalization of fragments of the professional worldview. Taking into account the cognitivediscursive characteristics of a legal term, we define it as a word or phrase that represents a fragment of the legal worldview and verbalizes the cognitive terminological structure in legal discourse.

Recently, among various terminological systems, the legal one, studied both as a system of linguistic signs of a secondary nomination and elements of juridical technique, began to expand with the nominations, which in the field of this terminological system turned from the units of common use to the conceptual structures of terminological nature - units of professional awareness, in which fragments of the professional worldview are concentrated and which have a verbal realization in the form of terms. One of such terminological structures in the legal field is the concept of REFUGEE (in English) and БІЖЕНЕЦЬ (in Ukrainian). 


\section{Historical and social foundations for the study of legal terms refugee / біженець}

Among the legal terms relating naming of a person, a special place is occupied by units reflecting the name of the personal legal status - "the legal position of a person in society, according to which an individual, as a subject of law, enters a legal relationship, coordinates their activities and behaviour in society" (Skakun, 2010, p. 57).

In the legal sciences, the types of legal status are distributed according to the subjects of legal relations, namely, "the status of citizens, foreigners, stateless persons, individuals with dual nationality, refugees, Ukrainian citizens abroad; the status of civil servants and officials (deputy, minister, investigator, judge, prosecutor, head of regional state administration, etc.); the status of persons working under the extreme conditions (defence facilities, secret factories), etc." (Skakun, 2010, p. 61). There are many classification features for distinguishing statuses, but the status based on citizenship is of interest to our study: a foreign citizen, a stateless person, a refugee, a forced migrant etc.

One of the lexemes that denominates an important social phenomenon of the present and has a specific semantic content in English and Ukrainian is the multisectoral terminological unit refugee / біженець, which includes the legal discourse among the areas of its active functioning.

The refugee problem is not new. It has accompanied the entire history of mankind alongside wars and conflicts. In today's world, the lexeme refugee is a unit of common use. For example, in the English language, the lexeme refugee is one of the 10,000 most commonly used words in the dictionary "Collins COBUILD English Language Dictionary" (Collins).

In 2015, in several languages at once the words denoting refugees and refugee-related phenomena became the words of the year: noun Flüchtlinge in German (Gesellschaft für deutsche Sprache - https://gfds.de/wort-desjahres-2015/\#), Flygtningestrømme in Danish (DR - https://www.dr.dk/ nyheder/kultur/flygtningestroemme-er-aarets-ord-2015), refugado in Spanish (Fundéu BBVA - https://www.fundeu.es/), uchodźca in Polish (Słowa na czasie - http://www.slowanaczasie.uw.edu.pl/), беженцы in Russian (Сноб https://snob.ru/profile/27356/blog/101993).

The Google Trends (Google), a search and analysis tool, provides access to mostly non-filtered samples of the actual Google search requests. These data are categorized (indicating the subject of the search request) and aggregated 
(grouped), thus, allowing to cover the interest on a given topic at both global and local levels.

Quantitative indicators demonstrate the popularity of the search term in regard to the highest point on the graph for a particular region and time period. 100 is the peak of the term's popularity. 50 means that the popularity of the term is twice less. 0 means that there was not enough data about this term.

The following monitoring criteria and characteristics have been selected for the analysis of the frequency of the queries formation with the search terms refugee and біженець:

1) region - to represent the use of the language, the United States of America and Great Britain - for the English language, Ukraine - for the Ukrainian language;

2) time period - from 01.01.2014 to 01.01.2020. The timing is based on the intensification of social events that refer to (directly and indirectly) and on which the functioning and set and transformation trends of the characteristics of the REFUGEE / БІЖЕНЕЦЬ subject area units depend.



Figure 1. Popularity of the search term refugee; period - 01.01.2014-01.01.2020; region - the United States of America; query language - English (Google). 


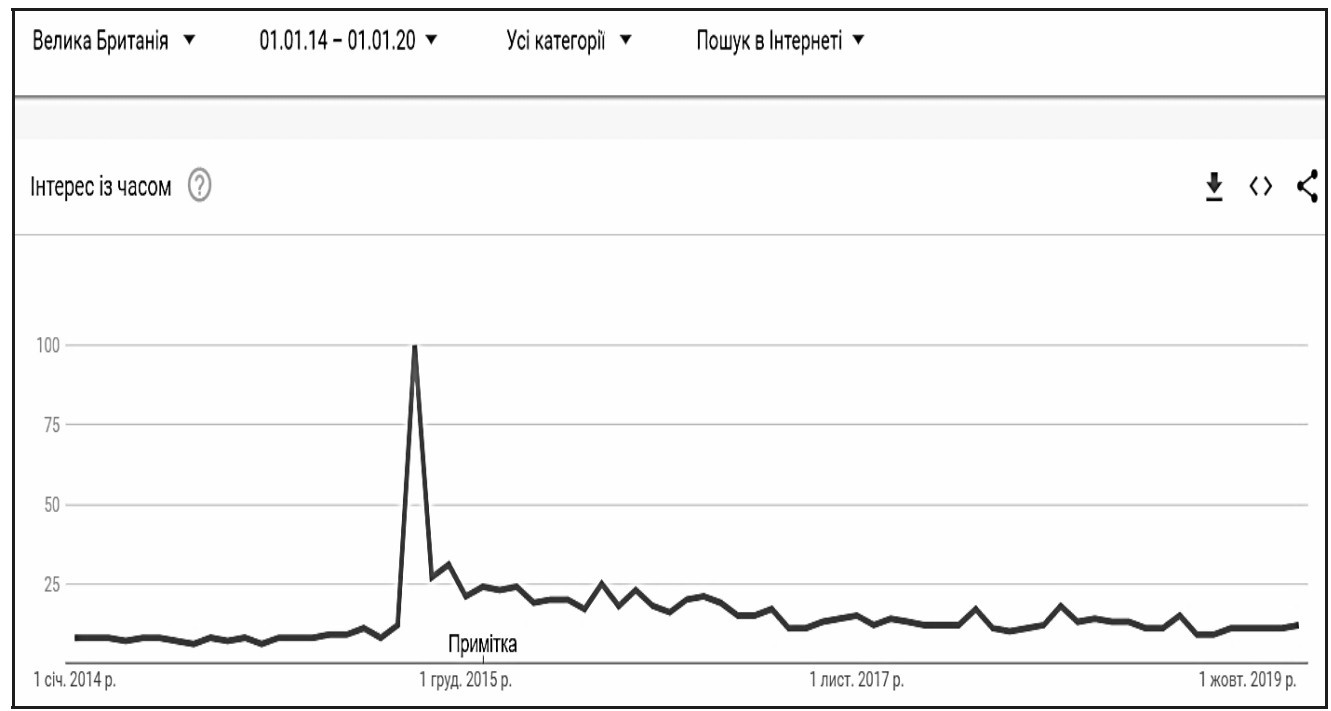

Figure 2. Popularity of the search term refugee; period - 01.01.2014-01.01.2020; region - Great Britain; query language - English (Google).

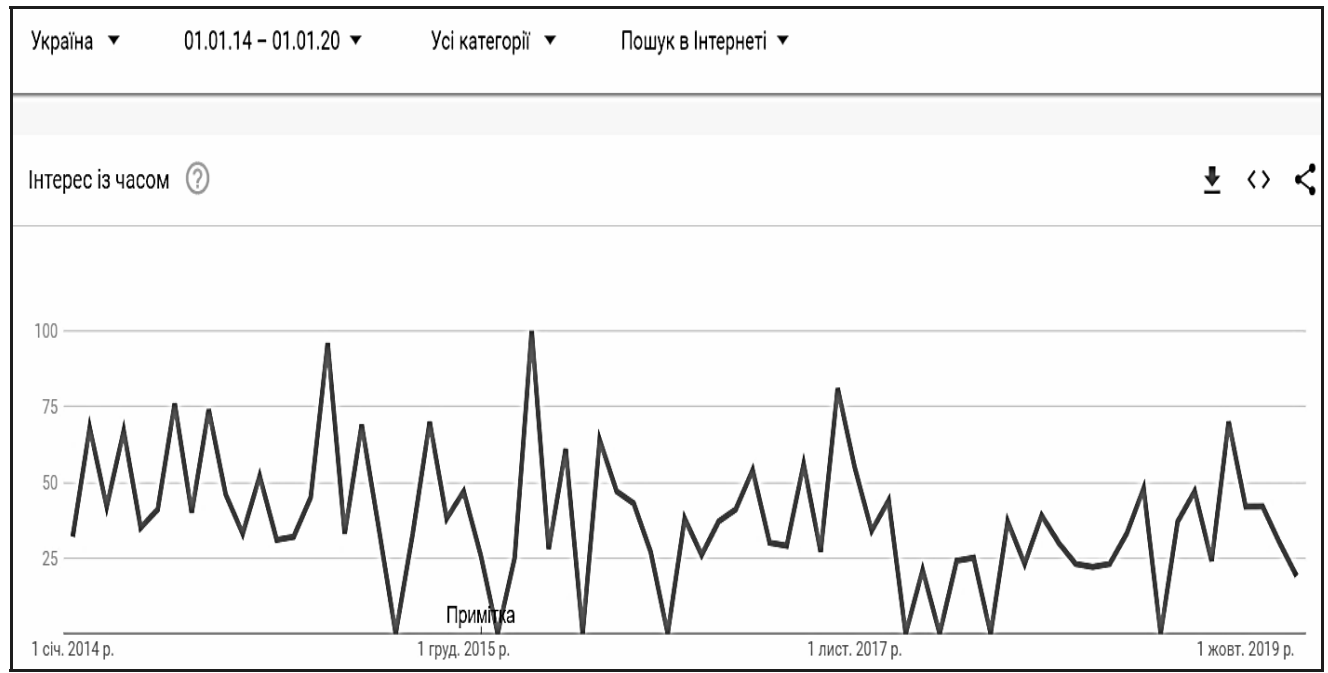

Figure 3. Popularity of the search term біженець; period - 01.01.2014-01.01.2020; region - Ukraine; query language - Ukrainian (Google).

The data obtained show differences in the frequency of use of the units refugee and біженець by English and Ukrainian speakers, respectively. At the same time, there are similarities (particularly at the peak point) between the European and American regions. Regarding the use of the term біженець in the Ukrainian language, we have noted a slight decline in activity over 
the past three years: $100 \rightarrow 81 \rightarrow 70$ (the last three peaks), which we primarily relate to the country's internal social and political events.

When analysing the use of these lexemes in two languages, it is also necessary to take into account the fact that English is the language of international communication and requests within Ukraine are formulated in Ukrainian as well as in English. Comparison of the use of the lexemes refugee (in English) and біженець (in Ukrainian) in the search query in Ukraine shows the following results:



Figure 4. Popularity of the search terms refugee (in English) and біженець (in Ukrainian); period - 01.01.2014 - 01.01.2020; region - Ukraine (Google).

As a complex problem that has not yet been solved in various aspects of society, refugee issues require special attention of the social and humanitarian experts from various points of view, in particular from the legal one.

\section{Evolution of the legal interpretation of the term refugee}

Every legal term has a long evolutionary path. The first official legal interpretation of the term refugee in the Russian Empire is contained in the refugee legislation of 1916. According to this source, "refugees are persons who have left the area, threatened or already occupied by the enemy, or who have been evicted by military or civilian authorities from the area 
of military operations, as well as immigrants of States hostile to Russia" (Zakony, 1916, p. 2).

The legal interpretation of the term refugee in the modern sense was first provided in the 1951 United Nations Convention relating to the Status of Refugees. According to this Convention, a refugee is "any person who ... owing to well-founded fear of being persecuted for reasons of race, religion, nationality, membership of a particular social group or political opinion, is outside the country of his nationality and is unable or, owing to such fear, is unwilling to avail himself of the protection of that country; or who, not having a nationality and being outside the country of his former habitual residence as a result of such events, is unable or, owing to such fear, is unwilling to return to it" (Convention).

As this definition was intended to provide a legal basis for resolving refugee issues in the post World War II years, it later needed to be supplemented and clarified, because such social transformations often require legislative changes in the definition of the term. Thus, in 1984, the definition of refugee was significantly broadened in response to the pressing needs of society - representatives of 10 Latin American countries signed the Cartagena Declaration on Refugees, in which to the understanding of refugees the following was added: "persons who have fled their country because their lives, safety or freedom have been threatened by generalized violence, foreign aggression, internal conflicts, massive violation of human rights or other circumstances which have seriously disturbed public order" (The Cartagena).

The definition of refugee in the EU Qualification Directive was significantly modified: "a third-country national who, owing to a well-founded fear of being persecuted for reasons of race, religion, nationality, political opinion or membership of a particular social group, is outside the country of nationality and is unable or, owing to such fear, is unwilling to avail himself or herself of the protection of that country, or a stateless person, who, being outside of the country of former habitual residence for the same reasons as mentioned above, is unable or, owing to such fear, unwilling to return to it" (EUR-Lex).

The Official multilingual and multidisciplinary thesaurus of the European Union interprets the term refugee as "someone who is unable or unwilling to return to their country of origin owing to a well-founded fear of being persecuted for reasons of race, religion, nationality, membership of a particular social group, or political opinion" (EU). The thesaurus also notes that this term 
refers to the thematic block of international relations / concept scheme international security /concept international issue.

These definitions show the existence of lexical units for specific legal phenomena as a third-country national, a stateless person, which determine the legal status of the individual, its legal links with the country and reinforce the differential component of the lexical meaning of the term and take into account the realities of the European present.

The terms refugee and біженець in their internal content include a wide range of legal relationships. So, from a legal point of view, a refugee is one who fulfils two basic conditions:

1) cause(s) - justified fear and suffering from persecution for one of the reasons (race, religion, nationality, belonging to a certain social group, political beliefs, etc.);

2) effect(s) - left the country of their permanent residence or citizenship / nationality, is outside the country of their citizenship and is unable to return to the country of their citizenship due to fear of persecution.

It is these semes that form the lexical industry-specific meaning of the legal terms refugee and біженець. All interpretations of this unit can be divided into two types: the person in question as the subject of the act and the person as the object of the act. In addition, the implicit legal information emerges from the above definitions: refugees are persons whose human rights have been violated and who require international (outside their country of nationality) protection.

\section{Thesaurus links of subject category refugee / біженець}

Genus-species relations in the lexical-semantic system is an important source of terminological information. The terminological system of each area is based on rationally related and interrelated terms, which influence each other. Such connected terms work together to ensure the integrity and stability of industry-specific terminology. The analysis of the meaning and function network of the term depends significantly on the units surrounding it. Associative relationships are a kind of dictionary scheme containing units with the psychological associations formed between them. By linking the meanings and relationships between such units, it is possible to enrich the meaning of the term and to describe its place in the system of the professional worldview.

The official UNESCO website contains the dictionary "UNESCO Thesaurus" (UNESCO). It is an ordered, controlled and structured list of terms 
used for thematic and subject analysis and document search, i.e., the thesaurus is a search tool in a narrow thematic and industry-specific information search engine.

The refugee lexeme request showed the following results presented in Figure 5:

\begin{tabular}{|c|c|c|c|}
\hline \multicolumn{3}{|l|}{ UNESCO Thesaurus } & Content language English r \\
\hline Alphabetical Hierarchy & Groups & Migrants $>$ Refugees & \multirow[b]{2}{*}{ Refugees search in UNESDOC } \\
\hline \multirow{7}{*}{$\begin{array}{l}\text {-Migrants } \\
\text { Displaced persons } \\
\text { Exiles } \\
\text { Foreigners } \\
\text {-mmigrants } \\
\text { Migrant workers } \\
\text { - Nomads } \\
\text { Refugees }\end{array}$} & & PREFERRED TERM & \\
\hline & & BROADER CONCEPT & Migrants \\
\hline & & RELATED CONCEPTS & $\begin{array}{l}\text { Disadvantaged groups } \\
\text { Humanitarian assistance } \\
\text { Refugee education } \\
\text { Right to seek asylum } \\
\text { Social problems } \\
\text { War devastated countries }\end{array}$ \\
\hline & & BELONGS TO GROUP & Social and human sciences $>$ Population \\
\hline & & IN OTHER LANGUAGES & $\begin{array}{ll}\text { Réfugié } & \text { French } \\
\text { Беженцы } & \text { Russian } \\
\text { Refugiado } & \text { Spanish }\end{array}$ \\
\hline & & URI & http://vocabularies.unesco.org/thesaurus/concept8119 \\
\hline & & Download this concept: & RDF/XML TURTLE JSON-LD \\
\hline
\end{tabular}

Figure 5. The thesaurus fragment of the term refugee, presented on the UNESCO

(UNESCO) website

In the given fragment of the thesaurus, the unit of broader content to the noun refugee is the term migrant, with the related units- disadvantaged groups, humanitarian assistance, refugee education, right to seek asylum, social problems, war devastated countries (UNESCO).

The "Visuwords" resource offers a visualized scheme of associative links of the term refugee: 


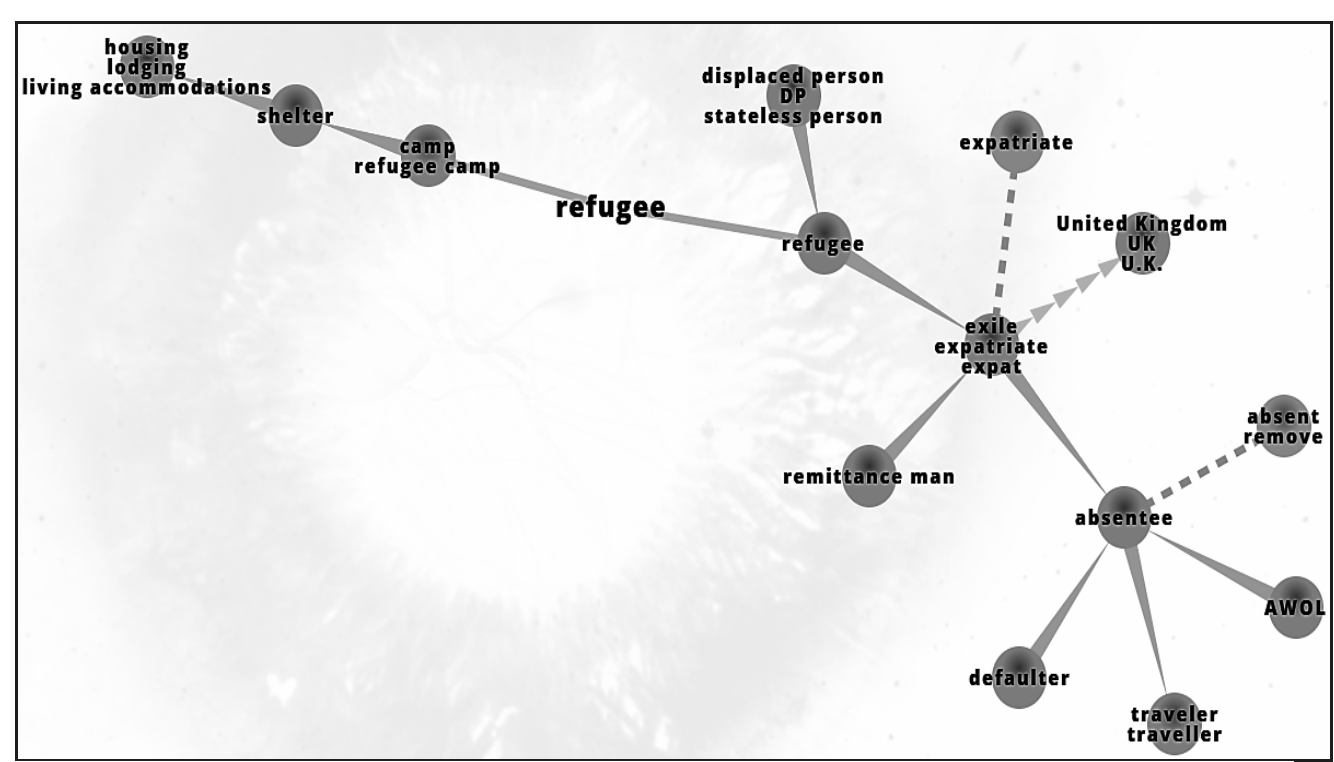

Figure 6. The thesaurus fragment of the term refugee, presented on the Visuwords website (Visuwords)

Next to the associative links, the proposed model also contains elements of hyper-homonymic bonds:

exile / expatriate / expat $\rightarrow$ refugee $\rightarrow$ displaced / DP / stateless person.

The "General Multilingual Environmental Thesaurus" resource defines, that the concept Social Group has broader meaning than the term refugee, the thematic group to which the refugee term belongs is the Social Aspects group, Society subgroup (General).

Thus, structuring a separate text as well as the language material of the entire subject area provides an opportunity to reach the more global level of structuring the knowledge of a particular professional area. Associative bonds ensure the coherence of the entire text as a speech product and as a form of organization of the discursive space. A term integrated into a special text, building hyper-hyponymy, synonymous and associative bonds, discloses its conceptual meaning and provides the speaker with additional tools to interpret the linked units within the verbal cognitive terminological structure.

\section{Conclusions}

So, as the phenomenon of refugees has evolved over time, it has attracted the professional attention of specialists from various social and humanitarian fields of science and society. The lexeme of common use acquires the content 
needed for serving certain scientific domains, i.e., the meaning of the lexical unit of the common language is redefined, that is reflected in the terminologization of the language unit.

The universality of the REFUGEE / БІЖЕНЕЦЬ cognitive terminological structure has been formed in the global public space, that is primarily due to the nature of the phenomenon itself, which it denotes - the movement of people from a country with negative conditions and circumstances of life to a country with a better situation. Naturally, the universal features of this concept have influenced the specificity of the cognitive terminological structure REFUGEE / БІЖЕНЕЦЬ that functions in various professional (including legal) discourses of each society.

Being updated in a certain professional discourse, the concepts create a network of subject area, evoke the cognitive term-structure in a speaker's mind, that is verbalized by the term in a specific communicative situation. This process of verbalization is influenced not only by objective professional circumstances, but also by a host of historical, cultural, social, temporary, personal and other factors.

\section{REFERENCES}

Collins COBUILD English Language Dictionary. URL: https://www.collinsdictionary.com (05.09.2020).

Convention and Protocol relating to the Status of Refugees. URL: https://www.unhcr.org/ protection/basic/3b66c2aa10/convention-protocol-relating-status-refugees.html (22.09.2020)

DR. URL: https://www.dr.dk/nyheder/kultur/flygtningestroemme-er-aarets-ord-2015 (12.09.2020).

EUR-Lex. The Qualifications Directive. URL: https://eur-lex.europa.eu/eli/dir/2011/95/oj (22.09.2020).

EU Vocabularies. URL: https://op.europa.eu/en/web/eu-vocabularies (05.09.2020).

Fundéu BBVA. URL: https://www.fundeu.es/ (05.09.2020).

General Multilingual Environmental Thesaurus. URL: https://www.eionet.europa.eu/ gemet/en/ themes (05.09.2020).

Gesellschaft für deutsche Sprache. URL: https://gfds.de/wort-des-jahres-2015/\# (12.09.2020).

Google Trends. URL: www.google.com/trends (12.09.2020).

Skakun, O.F. (2010). Teoriya prava i derzhavy. Kyyiv: Alerta; KNT; TsUL, 2010 (05.09.2020).

Słowa na czasie. URL: http://www.slowanaczasie.uw.edu.pl/ (22.09.2020).

Сноб. URL: https://snob.ru/profile/27356/blog/101993 (12.09.2020).

The Cartagena Declaration on Refugees. URL: http://www.refugeelegalaidinformation.org/ cartagena-declaration-refugees (05.09.2020).

UNESCO Thesaurus. URL: http://vocabularies.unesco.org (12.09.2020). 
Visuwords. URL: https://visuwords.com (05.09.2020).

Zakony i rasporyazheniya o bezhentsah. (1916). Vyp. 1. Moskva: Yurid. otd. Glav. komit. Vseros. soyuza gorodov. URL: http://elib.shpl.ru/ru/nodes/19917\#mode/inspect/ page/1/zoom/4 (05.09.2020). 